\title{
Growing Degree Days Accumulation of Wheat (Triticum aestivum L.) Cultivars as Influenced by Different Nitrogen Level
}

\author{
Sukhpreet Kaur Sidhu* and Tilak Raj
}

Department of Botany, Punjab Agricultural University, Ludhiana 141004, Punjab, India

*Corresponding author

\section{A B S T R A C T}

\section{Keywords \\ Wheat Cultivars \\ Phenology, Nitrogen \\ Doses, Regression model, \\ Growing degree days \\ Article Info \\ Accepted: \\ 20 August 2018 \\ Available Online: \\ 10 September 2018}

\begin{abstract}
A field experiment was conducted to work out relationship between growing degree days and phenophases of three wheat cultivars (PBW-550, PBW-502 and PBW-343) under two nitrogen doses@120 and $180 \mathrm{~kg} \mathrm{~N} \mathrm{ha}^{-1}$, respectively. There was 18.94 percent reduction in growing degree days (GDD) at physiological maturity under120 kg ha-1 nitrogen level cumulative in comparison to $180 \mathrm{~kg} \mathrm{~N} \mathrm{ha}^{-1}$. It was concluded that Cultivar (Cv.) PBW-343 accumulated more growing degree days under both nitrogen levels. The reduction in growing degree days from $180 \mathrm{~kg} \mathrm{~N} \mathrm{ha}^{-1}$ to $120 \mathrm{~kg} \mathrm{~N}^{-1}$ was 9.27 per cent in $\mathrm{Cv}$. PBW502 followed by Cv. PBW-550 (8.63\%). The regression model revealed significant positive correlation between GDD and yield at booting $\left(\mathrm{R}^{2}=0.4709\right)$, leaf development completion $\left(\mathrm{R}^{2}=0.4415\right)$ and soft dough $\left(\mathrm{R}^{2}=0.3729\right)$.
\end{abstract}

\section{Introduction}

Wheat occupies prime position in modulating the economy of India. Yield of wheat is the final product of a complex system consisting of several sub-systems involving climate, soil production technology.

Climate change is a concern today, and researchers are engaged in understanding its impact on growth and yield of crops, and also identifying suitable management options to sustain the crops productivity under climate change scenarios. Seasonal temperature is an important climatic factor which can have profound effects on the yields of crops. Changes in seasonal temperature affect the grain yield, mainly through phenological development processes. A change in optimal temperature during its vegetative or reproductive growth adversely affects the onset and duration of phenophases and yield of a crop. It is therefore essential to have knowledge of the exact duration of development phases in a particular environment and their association with yield determinants for achieving high yield. Growing degree day is a good estimator of wheat growth stages (Pal et al., 1996). Accumulation of degree -days for each stage of development is relatively constant and independent of sowing date (Castillo and Santibanez, 1987). However, soil-moisture regimes and fertilizer management can modify it considerably (Stark and Longley, 1986). The present study aims to investigate the effects of 
different $\mathrm{N}$ levels on growing degree days accumulation for development of various phenophases of wheat. Plants have a definite temperature requirement before they attain certain phenological stages.

The accumulative heat units and system was assumed for determining the dates to flowering and maturity of different crops (Sikder, 2009). However, different phenophases vary in their sensitivity to abiotic stresses, and this relies on plant species and genotype as there are great inter and intraspecific variations (Howarth, 2005). It is high time to develop high yielding wheat varieties that are suitable to different stressful conditions.

\section{Materials and Methods}

A field experiment was conducted during the rabi season at Punjab Agricultural University, Ludhiana. Ludhiana representing the IndoGangetic alluvial plains is situated at $30^{\circ}-54^{\prime} \mathrm{N}$ latitude, $75^{\circ}-48^{\prime} \mathrm{E}$ longitude and at an altitude of $247 \mathrm{~m}$ above mean sea level. Ludhiana is placed in South-Central plain region of Punjab having subtropical and semi-arid climate.

The mean maximum and minimum temperature, therefore, shows considerable fluctuation during summer and winter seasons. The bread wheat cultivars used in this research programme were PBW-550, PBW-502 and PBW-343.

The experimental design was a split plot with three replications. Nitrogen was applied at a rate of 120 and $180 \mathrm{~kg} \mathrm{~N} \mathrm{ha}^{-1}$ respectively. The soil was loamy sand with alkaline $\mathrm{pH} 8.2$, available phosphorus $18.4 \mathrm{~kg} \mathrm{ha}^{-1}$ and available potassium $150 \mathrm{~kg} \mathrm{ha}^{-1}$ and nitrogen $130 \mathrm{~kg} \mathrm{ha}^{-1}$. The meteorological data was recorded during crop seasons by School of Climate Change and Agrometeorology, Punjab Agricultural University, Ludhiana (Fig. 1).

\section{Results and Discussion}

\section{Phenological development}

Changes in seasonal temperature affect the grain yield, mainly through phenological development processes. Phenological development from seedling to maturity is related to the accumulation of heat or temperature units above a base temperature below which no growth occurs. Phenological development and GDD of the cultivar PBW550, PBW-502 and PBW-343 under two levels of nitrogen presented in Fig. 2 i.e. from seedling emergence to physiological maturity.

\section{Seedling emergence}

In all varieties seedling emergence took 6 days under $120 \mathrm{~kg} \mathrm{~N} \mathrm{ha}^{-1}$. The number of days increased with increase in the nitrogen level from 120 to $180 \mathrm{~kg} \mathrm{~N} \mathrm{ha}^{-1}$. Under $180 \mathrm{~kg} \mathrm{~N}$ $\mathrm{ha}^{-1}$ PBW-550 and PBW-343 took 7 days while PBW-343 took 8 days. Number of days taken from seedling emergence depends on nitrogen and temperature. With increase in nitrogen level the crop took more days for the seedling emergence (Khan et al., 2008). The cumulative growing degree days increase with increase in nitrogen levels from 120 to $180 \mathrm{~kg}$ $\mathrm{N} \mathrm{ha}^{-1}$. The GDD required for the seedling emergence were maximum (116.8) in PBW343 under $180 \mathrm{~kg} \mathrm{~N}^{-1}$.

\section{Crown root initiation (CRI)}

The number of days taken by different wheat cultivars (PBW-550, PBW-502 and PBW343) for attainment of crown root initiation stage increased with increase in nitrogen levels from 120 to $180 \mathrm{~kg} \mathrm{~N} \mathrm{ha}^{-1}$. Cv. PBW550 took 16 days from sowing to CRI. Under $120 \mathrm{~kg} \mathrm{~N} \mathrm{ha}{ }^{-1} \mathrm{Cv}$. PBW-502 and PBW-343 took 17 days from sowing to CRI under 120 $\mathrm{kg} \mathrm{N}$ ha $^{-1}$. Under $180 \mathrm{~kg} \mathrm{~N}^{-1} \mathrm{Cv}$. PBW-550 took 18 days while PBW-502 and PBW-343 
took 19 days from sowing to CRI. There was increase in accumulated growing degree days (AGDD) with increase in nitrogen level. The significant difference occurred between nitrogen levels for attainment of crown root stage. Such observations of GDD have earlier reported by Anderson et al., (1995). The accumulated, growing degree days were maximum (24.32) under $180 \mathrm{~kg} \mathrm{~N} \mathrm{ha}^{-1}$.

\section{Leaf initiation}

The number of days taken for leaf initiation by different wheat varieties varied under different nitrogen levels. The varieties PBW-343 and PBW-502 took 24 days under $180 \mathrm{~kg} \mathrm{~N}$ ha $^{-1}$ level while PBW-550 took 23 days under same level. Under $120 \mathrm{~kg} \mathrm{~N}^{-1} \mathrm{PBW}-550$ took less days (21) as compared to PBW-502 (22) and PBW-343 (22). The accumulated GDD units increased with increase in nitrogen levels. PBW-502 and PBW-343 varieties took maximum (300) GDD units followed by PBW-550 (287.5) at $180 \mathrm{~kg} \mathrm{~N}^{-1}$. The results are in conformity with Miglietia (1991).

\section{Leaf development completion}

The number of days taken for leaf development stage by different wheat varieties varied under different nitrogen levels. The variety PBW-343 took more number of days i.e. 84 under $180 \mathrm{~kg} \mathrm{~N}^{-1}$ followed by PBW502 (83) and PBW-550 (82) varieties. The PBW-550 took lesser (79) days under $120 \mathrm{~kg}$ $\mathrm{N}$ ha $^{-1}$ from sowing to complete leaf development stage. The number of days for leaf development increased with increase in nitrogen levels from 120 to $180 \mathrm{~kg} \mathrm{~N}^{-1}$. The accumulated GDD units increased with increase in nitrogen level. PBW-343 variety took maximum (840) GDD units followed by PBW-502 (830) and PBW-550 (820) variety under $180 \mathrm{~kg} \mathrm{~N}^{-1}$. Under $120 \mathrm{~kg} \mathrm{~N}^{-1}$ PBW-343 (787.8) took more GDD as compared to PBW-502 (797.9) and PBW-550
(797.7). These results are close with the findings of Miglietta (1991).

\section{Tillering initiation}

The number of days taken for the attainment of tillering initiation increased with increase in nitrogen levels from 120 to $180 \mathrm{~kg} \mathrm{~N}^{-1}$ in all varieties. The increase in number of days taken for tillering initiation due to increase in nitrogen level. Longnecker et al., (1993) also reported increased number of days with increase in nitrogen levels. The accumulated growing degree days were maximum for all cultivars under $180 \mathrm{~kg} \mathrm{~N}^{-1}$. The $\mathrm{Cv}$. PBW343 accumulate more (359.6) GDD which was followed by PBW-502 (350) and PBW-550 (337.5) under $180 \mathrm{~kg} \mathrm{~N} \mathrm{ha}^{-1}$, the accumulated (287.5) under $120 \mathrm{~kg} \mathrm{~N} \mathrm{ha}^{-1}$.

\section{Tillering completion}

The number of days taken for the completion of tillering stage increased with increase in nitrogen levels from 120 to $180 \mathrm{~kg} \mathrm{~N} \mathrm{ha}^{-1}$. The accumulated growing degree days were maximum in Cv. PBW-343 (787.8) followed by PBW-502 (777.7) and PBW-550 (767.6) under $180 \mathrm{~kg} \mathrm{~N}^{-1}$. Under $120 \mathrm{~kg} \mathrm{~N}^{-1}$ PBW-550 (757.5) accumulated maximum growing degree days than PBW-502 (747.4) and PBW-343 (747.4). Cv. PBW-343 (78) took more days than PBW-550 (76) and PBW502 (77) from sowing to tillering completion. These results are in conformity with Longnecker et al., (1993). The results indicate the effect of nitrogen, temperature and sunshine hours during the crop growing season.

\section{Jointing (stem elongation)}

The number of days taken up by the crop to complete jointing stage varied with both variety and nitrogen levels. The number of days increased with increase in nitrogen levels 
from 120 to $180 \mathrm{~kg} \mathrm{~N} \mathrm{ha}^{-1}$. The $\mathrm{Cv}$. PBW-343 and PBW-502 took maximum number of days (80) under $180 \mathrm{~kg} \mathrm{~N}^{-1}$ level while PBW550 took 79 number of days from sowing to jointing stage. PBW-550 requires minimum number of days (76) for attainment of jointing stages under $120 \mathrm{~kg} \mathrm{~N} \mathrm{ha}{ }^{-1}$. The number of days increased with increase in nitrogen levels from 120 to $180 \mathrm{~kg} \mathrm{~N} \mathrm{ha}^{-1}$. The accumulated GDD were increased with increase in nitrogen levels. PBW-343 accumulated maximum GDD (808) followed by PBW-502 (800) and PBW-550 (797.9) under $180 \mathrm{~kg} \mathrm{~N} \mathrm{ha}{ }^{-1}$. Under $120 \mathrm{~kg} \mathrm{~N} \mathrm{ha}{ }^{-1}$ PBW-343 (787.8) accumulated maximum GDD then PBW-502 (777.7) and PBW-550 (767.6). The results are in close conformity with Qi et al., (2009).

\section{Booting}

The number of days taken for the attainment of booting stage increased as the level of nitrogen increased from 120 to $180 \mathrm{~kg} \mathrm{~N} \mathrm{ha}^{-1}$. The Cv. PBW-502 took more (108) days followed by PBW-343 (107) and PBW-550 (106) under $180 \mathrm{~kg} \mathrm{~N} \mathrm{ha}^{-1}$. The increased days with increase in nitrogen levels has also been reported by Maranville (1994). The maximum accumulated GDD recorded in Cv. PBW-502 (1112.14) followed by PBW-343 (1102.1) and PBW-550 (1091.8) under $180 \mathrm{~kg} \mathrm{~N} \mathrm{ha}{ }^{-1}$. Under $120 \mathrm{~kg} \mathrm{~N}^{-1} \mathrm{Cv}$. PBW-550 (1050.6) accumulated lesser growing degree days as compared to PBW-343 (1060.9) and PBW502 (1040.4).

\section{Ear emergence}

The number of days taken for the emergence of inflorescence increases as the nitrogen levels increased. The number of days taken were maximum in PBW-502 (109) while minimum in PBW-550 (107) cultivar under $180 \mathrm{~kg} \mathrm{~N} \mathrm{ha}^{-1}$. Under $120 \mathrm{~kg} \mathrm{~N} \mathrm{ha}^{-1}$ number of days taken were maximum in PBW-343 (106) followed by PBW-502 (105) and PBW-550 (104) cultivars. The Cv. PBW-502 (1122.7) accumulated more growing degree days (GDD) while PBW-343 (1112.4) and PBW550 (1102.1) under $180 \mathrm{~kg} \mathrm{~N}^{-1}$. Cv. PBW343 (1091.8) accumulated more GDD than PBW-502 (1081.5) and PBW-550 (1060.8) at $120 \mathrm{~kg} \mathrm{~N} \mathrm{ha}^{-1}$.

\section{Ear heading}

The number of days taken for completion of this stage increased with increase in nitrogen levels. The accumulated growing degree days maximum in PBW-343 (1197) while minimum in PBW-550 (1122.7) under $180 \mathrm{~kg}$ $\mathrm{N}$ ha $^{-1}$. The Cv. PBW-343 (1142.4) accumulated more GDD, followed by PBW502 (1144) and PBW-550 (1144). These results are in conformity with Miglietta (1991).

\section{Anthesis}

The number of days taken from sowing to anthesis stage increased with increase in nitrogen levels. The GDD units were more accumulated in PBW-502 (1241.2).Cv. PBW353 (1241.2) also accumulated same GDD than PBW-550 (11.76) under $180 \mathrm{~kg} \mathrm{~N} \mathrm{ha}^{-1}$. At 120 and $180 \mathrm{~kg} \mathrm{~N}$ ha $^{-1} \mathrm{Cv}$. PBW-343 (1207.5) accumulated more GDD followed by PBW-502 (1197) and pBW-550 (1144). Similar results were also reported by Angus and Mancur (1985).

\section{Watery ripe}

The number of days to reach watering ripe stage increases with increase in the levels of nitrogen. The lesser number of days were observed in Cv. PBW-550 (116) followed by Cv. PBW-502 (117) and Cv. PBW-343 (118) under $120 \mathrm{~kg} \mathrm{~N} \mathrm{ha}^{-1}$. At same level Cv. PBW343 (1262.6) accumulated more growing degree days followed by PBW-502 (1251.9) and PBW-550 (1241.2). 
Fig.1 Daily maximum and minimum temperature (November to April)

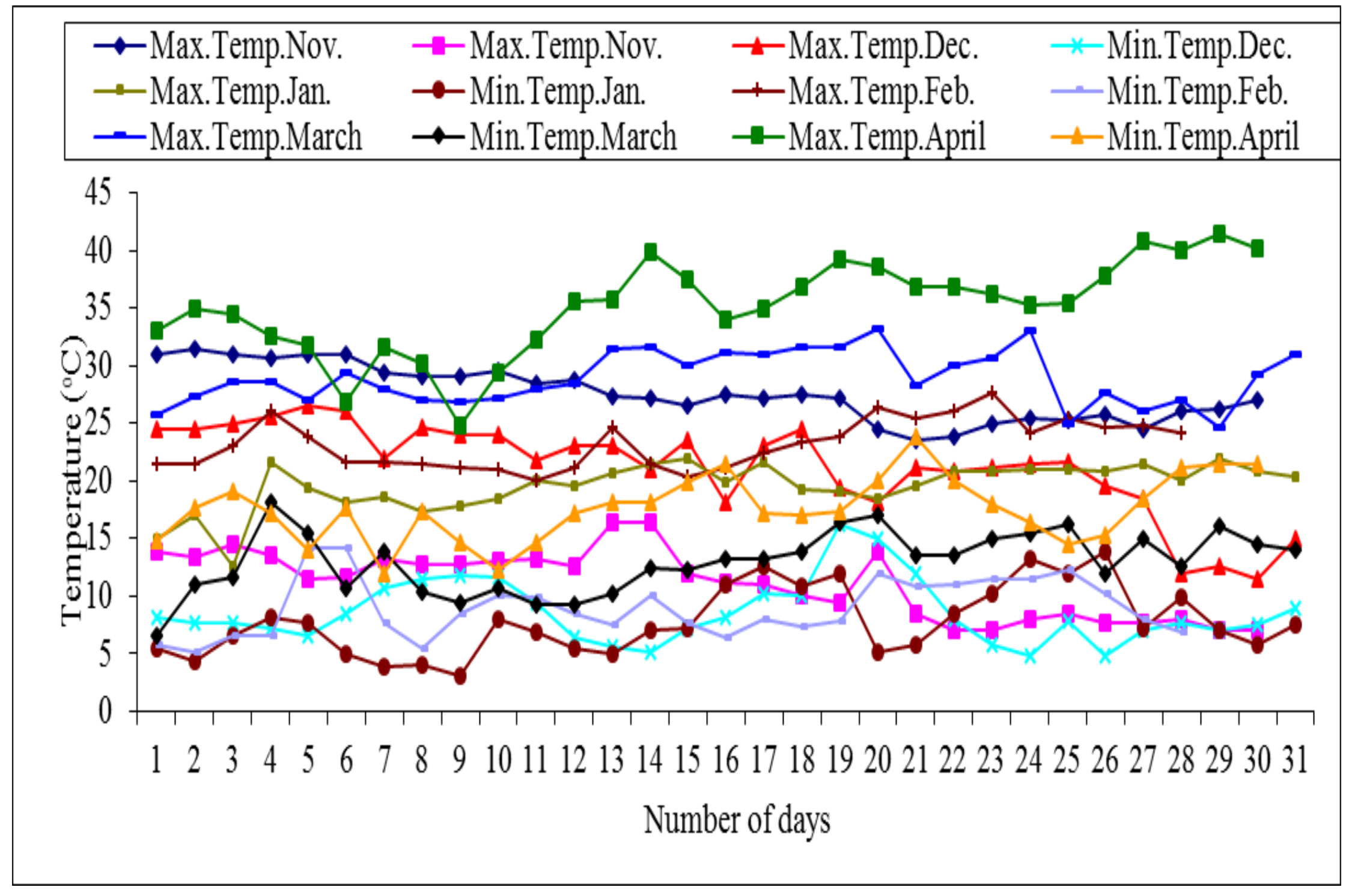


Fig.2 Phenological development of wheat cultivars

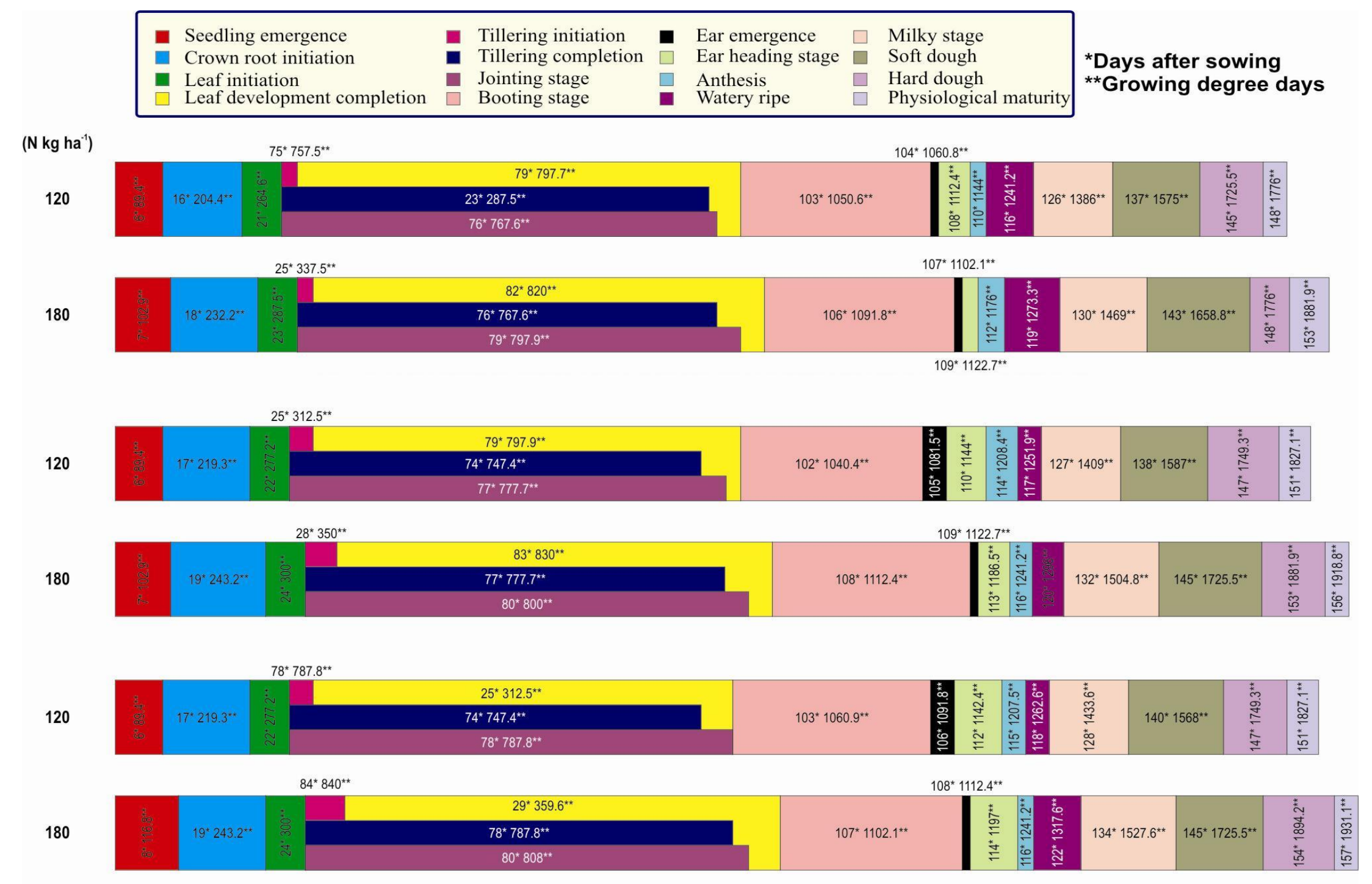


The GDD followed the increasing trend from 120 to $180 \mathrm{~kg} \mathrm{~N}^{-1}$. At $180 \mathrm{~kg} \mathrm{~N}^{-1} \mathrm{PBW}$ 343 (1317.6) accumulated more GDD as compared to PBW-502 (1296) and PBW-550 (1273.3).

\section{Milky ripe}

The number of days taken for milky ripe stage are more in PBW-343 (134) followed by PBW502 (132) and PBW-550 (130) under $180 \mathrm{~kg} \mathrm{~N}$ $\mathrm{ha}^{-1}$. The maximum accumulated GDD units were observed in PBW-343 (1527.6) followed by PBW-502 (1504.8) and PBW-550 (1469) under $180 \mathrm{~kg} \mathrm{~N} \mathrm{ha}{ }^{-1}$. At $120 \mathrm{~kg} \mathrm{~N} \mathrm{ha}^{-1}$ accumulated growing degree days are less in PBW-550 (1386) followed by PBW-502 (1409.7) and PBW-343 (1433.6). Gooding and Davies (1992) also reported increase in number of days by the effect of higher nitrogen levels.

\section{Soft dough}

The number of days and accumulation GDD increased with increase in nitrogen levels in all varieties. The Cv. PBW-502 and PBW-343 took same days (145) for soft dough stage followed by PBW-550 (143) under $180 \mathrm{~kg} \mathrm{~N} \mathrm{ha}^{-1}$ while at $120 \mathrm{~kg} \mathrm{~N}^{-1}$ PBW-343 took more days (140) followed by PBW-502 (138) and PBW-550 (137). Accumulated GDD more in PBW-343 (1725.5) followed by PBW-502 (1725.5) and PBW-550 (1658.8). The Cv. PBW-550 accumulated less growing degree days (1575.5) as compared to PBW-502 (1587) and PBW-343 (1568) at $120 \mathrm{~kg} \mathrm{~N} \mathrm{ha}^{-1}$ level. Similar results were reported by Khan et al., (2008).

\section{Hard dough}

The maximum number of days taken for the attainment of hard dough stage was observed in PBW-343 (154) followed by PBW-502 (153) and PBW-550 (148) under $180 \mathrm{~kg} N$ $\mathrm{ha}^{-1}$. Under $120 \mathrm{~kg} \mathrm{~N}$ ha $^{-1} \mathrm{PBW}-550$ took less days (145) as compared to PBW-502 (147) and PBW-343 (147). Maximum accumulated GDD were recorded under $180 \mathrm{~kg} \mathrm{~N}$ ha-1 in PBW343 (1894.2) followed by PBW-502 (1881.9) and PBW-550 (1776). The Cv. PBW-550 accumulated minimum GDD (1725.5) under $120 \mathrm{~kg} \mathrm{~N} \mathrm{ha}^{-1}$ as compared to other cultivars.

\section{Physiological maturity}

The wheat Cv. PBW-502 and PBW-343 took similar number of days (151) under $12 \mathrm{~kg} \mathrm{~N}^{-1}$ while PBW-550 took (148) days from sowing to physiological maturity. The Cv. PBW-343 took maximum day (157) for physiological maturity followed by PBW-502 (156) and PBW-550 (153) under $\quad 180 \quad \mathrm{~kg} \quad \mathrm{~N}$ $\mathrm{ha}^{-1}$.

The accumulated growing degree days in all wheat varieties increased with increase in nitrogen levels from 120 to $180 \mathrm{~kg} \mathrm{~N} \mathrm{ha}^{-1}$. The Cv. PBW-502 and PBW-343 accumulated same GDD (1827.1) at $120 \mathrm{~kg} \mathrm{~N} \mathrm{ha}^{-1}$. At $180 \mathrm{~kg} \mathrm{~N}^{-}$ ${ }^{1}$ Cv. PBW-550 accumulated less GDD (1881.9) as compared to other varieties. Yang et al., (2000) showed that both grain growth rate and grain growth duration were affected by different nitrogen levels.

\section{Regerssion equations for phenological development}

The regression equation indicating the relationship of grain yield with growing degree days units accumulated during different phenophases of wheat are presented in Fig. 3.

Regression analysis revealed a significant positive correlation between grain yield and growing degree days accumulated during grain ripening stages. Linear regression equations, taking phenophasic data pooled over two nitrogen levels (120 and $180 \mathrm{~kg} \mathrm{~N} \mathrm{ha}^{-1}$ ) and three varieties were derived for predicting the yield bases on number of days taken for achieving particular growth stage. Regression analysis indicated a significant positive correlation between grain yield and growing degree days during booting stage $(\mathrm{R} 2=0.470)$, crown root initiation $(\mathrm{R} 2=0.441)$ and soft dough $(\mathrm{R} 2=0.372)$. 
From the data of growing degree days we can predict the yield of wheat crop in a particular season. The GDD depends on variation in maximum and minimum temperature of the air. So, growing degree days give better prediction of yield. From these equations we can also explain the variation in yield on the basis of accumulated growing degree days.

\section{References}

Anderson W K, Crosbie G B and Lemsom K. 1995. Production practices for high protein, hard wheat in Western Australia. Aust J ExpAgric 35: 589-95.

Angus J F and Moncur M W. 1985. Models of growth and development of wheat in relation to plant nitrogen. Aust J Agric Res 36: 537-44.

Castillo G H, Santibanez Q F. 1987. Effect of temperature on phenology of wheat. Agricultura Tecnica 47:29-32.

Gooding M J and Davies W P. 1997. Wheat production and utilization. $\mathrm{CAB}$ Int., Wallingford, UK.

Howarth C J. 2005. "Genetic improvements of tolerance to high temperature," in Abiotic Stresses: Plant Resistance Through Breeding and Molecular Approaches, M. Ashraf and P. J. C. Harris, Eds., Howarth Press, New York, NY, USA.

Khan A, Jan M T, ArifM, Marwat B and Jan A. 2008.Phenology and crop stand of wheat as affected by nitrogen and tillage systems. Pak. J. Bot 40:1103-12.

Longnecker N, Kirby E J M and Robson A. 1993. Leaf Emergence, Tiller Growth, and Apical Development of NitrogenDeficient Spring Wheat. Crop Sci 33:154160

Maranville J W. 1994. Response of wheat cultivars to different soil nitrogen and moisture regimes: I. Dry matter partitioning and root growth. J Plant Nutr 17:729-44.

Miglietta F. 1991. Simulation of wheat ontogenisis. III. Effect of variety, nitrogen fertilization and water stress on leaf appearance and final leaf number in the field. Clim Res 1:233-42.

Pal S K, Verma U N, Singh M K and Thakur K. 1996. Heat unit requirement for phenological development of wheat (Triticum aestivum) under different levels of irrigation, seeding date and fertilizer. Indian J AgricSci 66: 397-400.

Qi Y L, Zhang F C and Li K F. 2009. Effects of water deficit and nitrogen fertilization on winter wheat growth and nitrogen uptake. J Appl Eco 20:2399-405.

Sikder S. 2009. Accumulated heat unit and phenology of wheat cultivars as influenced by late sowing heat stress condition. Journal of Agriculture and Rural Development. 7: 57-64.

Stark J C, and Longley T S. 1986. Changes in spring wheat tillering patterns in response to delayed irrigation. Agron J 78: 892-6.

Yang J, Zhang J, Huang Z, Zhu Q and Wang L. 2000. Remobilization of carbon reserves is improved by controlled soil-drying during grain filling of wheat. Crop Sci 40: 1645-55.

\section{How to cite this article:}

Sukhpreet Kaur Sidhu and Tilak Raj. 2018. Growing Degree Days Accumulation of Wheat (Triticum aestivum L.) Cultivars as Influenced by Different Nitrogen Level. Int.J.Curr.Microbiol.App.Sci. 7(09): 3041-3048. doi: https://doi.org/10.20546/ijcmas.2018.709.379 